\title{
Opportunities and Threats of Mediterranean Evergreen Sclerophyllous Woody Species Subjected to Extreme Drought Events
}

\author{
Filippo Bussotti (1) and Martina Pollastrini * \\ Department of Agriculture, Food, Environment and Forestry (DAGRI), University of Florence, \\ Piazzale delle Cascine 28, 50144 Firenze, Italy; filippo.bussotti@unifi.it \\ * Correspondence: martina.pollastrini@unifi.it; Tel.: +39-055-2755852
}

Received: 5 November 2020; Accepted: 25 November 2020; Published: 27 November 2020

check for updates

\begin{abstract}
Climate change and extreme drought and heat events impact the Mediterranean evergreen sclerophyllous vegetation in South Europe, especially in Iberian and Italian peninsula, where widespread crown defoliation and dieback have been observed since the 90 s of the XX century. Field observations and long-term experiments showed different sensitivity of the various woody species, Quercus ilex and Arbutus unedo being prone to drought, whereas Phillyrea latifolia and Pistacia lentiscus appeared to be resistant. The present review aims at exploring the phylogenetic and evolutionary basis of the resistance (or susceptibility) to drought of Mediterranean vegetation and its possible mechanisms of resilience. The main findings are summarized as follows: (1) Mediterranean regions in the world are refuge areas for several plant evolutive lineages and migratory routes. Evergreen sclerophyllous species, currently presented in Mediterranean basin, evolved under different climatic conditions; (2) the evergreen habitus represents an adaptation to mild drought conditions. Deciduous (specially summer deciduous) species are better performing under severe drought and low air relative humidity than evergreen species; (3) severe drought events acts selectively by favouring the species evolved in the Quaternary era and those originated in drier regions; (4) the evergreen trees and shrubs are resilient to the severe drought events and can restore the pre-event condition by resprouting from dormant buds in the cambium tissue. This ability is related to the non-structural carbohydrate content in the parenchyma-rays in woody stems. The amount and availability of these strategic reserve can be compromised by frequent drought events; (5) plant seed regeneration can be affected by drought and seedling establishment may be limited by soil dryness and microenvironment conditions; (6) the role of phenotypic plasticity of the species and epigenetic responses in Mediterranean-type ecosystems, although discussed in few papers, is still poorly known. We hypothesize that instead of latitudinal (South to North) or altitudinal (lowland to upland) plant migrations, Mediterranean forest ecosystems may respond to climate change by modulating their species composition and community structure with genetic resources (i.e., taxonomic diversity) already present in loco. Changes in vegetation assemblages and community structure may lead changes in ecological and landscape ecosystem values, with changes in related ecosystem services. A redefinition of management criteria of natural resources and a pro-active silviculture to make forest ecosystems more resilient are required.
\end{abstract}

Keywords: climate change; drought resistance; evergreeness; sclerophylly; resilience; resprouting capacity; severe drought events; species origin; vegetation changes 


\section{Introduction}

Widespread forest tree mortality and dieback caused by drought and temperature stress (i.e., warm winters and hot summers), often followed by insect and pathogen attacks, is a worldwide problem connected to climate change [1-7]. In the last decades, European temperate forests were subjected to recurrent heat and drought waves, such as in 2003 and 2018 [8,9].

Mediterranean evergreen forests and shrublands, although considered well adapted and resistant to summer drought [10], were severely impacted in the Iberian Peninsula and in Italy, as reported by several papers [11-16]. Extreme climate events, including severe drought and heat waves, as described in these papers, affected selectively evergreen sclerophyllous species, both trees and shrubs. Quercus ilex L. and Arbutus unedo L. were the most sensitive species with severe crown dieback and high mortality rates, whereas Phillyrea latifolia L. and Pistacia lentiscus L. resulted in being resistant, with no or little crown damage (i.e., defoliation, branch and leaf desiccation). These findings were then confirmed in a long-term experiment of drought imposed in Catalunya [17].

We hypothesize that in ecosystems that are species-rich and have complex structures, such as the Mediterranean evergreen forests and shrubland, the worsening of climatic conditions, with increasing drought and extreme event frequency, will act as a factor triggering vegetational dynamics, modifying plant species composition, individual interactions in resource use and structure of the stands [18].

\section{Is Sclerophylly Related to Drought Resistance?}

The dominance of evergreen sclerophyllous trees and shrubs in forest ecosystems is a common trait that characterizes the Mediterranean-type vegetation in different regions of the world [19]. It is generally accepted that sclerophylly and evergreeness are adaptive strategies to cope with several environmental factors [20,21], such as the lack of nutrients in the soils [22,23], and to optimize the metabolic costs for the construction of leaves by means of longer lifespan and economy of nutrients [23].

The different strategies of evergreen sclerophyllous and deciduous species to cope with severe summer drought have been largely debated [21,22]. Drought-deciduous species, dropping leaves in late summer or even earlier under extreme water stress, can avoid the most severe physiological consequences [24]. Differently, evergreen sclerophylls do not lose their leaves, perhaps because of the greater metabolic cost for the plant to build the photosynthetic apparatus, than in a deciduous species. Mediterranean deciduous species are built to recover nutrients from leaves prior to their abscission [25]; once the deciduous species has lost its leaves, they have more of a physiological advantage to deal with drought than the evergreens. Where strong water stress is common in summer, growing conditions for plants, generally, occur in late spring; later environmental conditions become progressively harsher, until soil moisture reaches the minimum level at the end of summer. In evergreen species, autumn and winter photosynthesis can be limited by low light availability and soil moisture; consequently, a positive carbon budget may not always be possible. Therefore, early leaf loss in deciduous species may be more efficient than evergreeness [22].

Deciduous trees and shrubs have more rapid maximum photosynthetic rates and can annually grow quickly than evergreens, [26,27]. Evergreen sclerophylls have a lower rate of photosynthesis at that time, although they maintain a relatively stable rate of net photosynthesis throughout the year thanks to the winter photosynthesis. Evergreen Mediterranean species compensate their lower mesophyll $\mathrm{CO}_{2}$ conductance with high carboxylation rate, reaching a photosynthesis level similar to deciduous plants [28]. Evergreen species manage to do this thanks to their larger leaf mass per area.

Some studies compared the relative behavior of co-occurring deciduous and evergreen species in Mediterranean environments. According to [29,30], Quercus pubescens Willd. (deciduous) has a lower construction cost (per leaf area, i.e., metabolic investment to assemblate the photosynthetic apparatus) than $Q$. ilex (evergreen), without difference in carbon assimilation rate. Despite different leaf biochemical composition, size and mass per unit area, the two oak species have similar responses to water shortage. Tognetti et al. [31], comparing the physiological behaviour of Q. pubescens and Q. ilex in natural stands under summer water stress, concluded that although highly tolerant to severe water 
stress and tissue dehydration, both species operate at the limits of hydraulic safety. Prolonged climate stress might predispose these Quercus species to physiological decline and dieback because their limits of hydraulic safety can be surpassed with frequent and repeated stress occurrence.

Vulnerability or resistance to extreme drought is rather related to the xylem characteristics than to leaf sclerophylly and phenology, and the recovery capacity from xylem embolism plays a crucial role [32] in sclerophyllous trees' responses to drought stress. Xylem vulnerability and recovery capacity are related to wood anatomy, including wood density; vessel diameter; pith size; mechanical elements, like fibers; and non-structural carbohydrates (NSC) storage in the parenchyma [33-36]. Sclerophyll species skillfully manage the water stress recovery, with a complete resolution of xylem cavitation, by means of simultaneous rehydration of the leaf apoplast and symplast [32].

The great elasticity of xylem cavitation strain of sclerophyll species depicts tree response to a large drop in stem water potential during the day, followed by night recovery [32]. This usually occurs in Mediterranean sclerophylls, because they grow with high irradiance and air temperature during the day and with high air humidity condensing on the soil surface at night. Differently, where air relative humidity is low, it is advanced the presence of drought deciduous species, such as Phlomis fruticosa L., [37].

\section{Does Evolutionary History Explicate the Resistance or Sensitivity to Climate Change?}

Some authors $[21,38]$ suggest that evergreen species react better to mild temperature seasonal fluctuations and to the absence of pronounced drought periods. In other words, evergreens are better adapted to semi-arid conditions in which dry spells are relatively short, while deciduous taxa may be better adapted to long (i.e., seasonal) droughts. The sclerophylly of Mediterranean species is hypothesized to originate from a similarity in leaf anatomical structure between species formerly adapted to humid environments, like tropical taxa, which later migrated to arid zones [39]. Indeed, the Mediterranean climate originated in the Quaternary [40-42], and the morpho-anatomical characteristics of plants that sign the evolutionary convergence between genera and species were evolved in Tertiary [39]. The current trait similarities among Mediterranean and tropical taxa may be due to phylogenetic constraints rather than evolutionary convergence [39-41]. These Authors argue that the current sclerophyllous Mediterranean vegetation derive from different evolutive lineages and migration routes and evolved partly from pre-adapted taxa from the Mediterranean basin, Macaronesia, and the tropics. Table 1 reports the era of origin of some relevant Mediterranean evergreen woody species.

Table 1. Mediterranean evergreen woody species listed on the basis of the era of origin.

\begin{tabular}{cc}
\hline Tertiary (Pre-Mediterranean $\left.{ }^{*}\right)$ & Quaternary (Mediterranean $\left.{ }^{*}\right)$ \\
\hline Abies cephalonica Loudon & Cistus albidus L. \\
\hline Abies numidica de Lannoy ex Carrière & Cistus creticus L. \\
\hline Arbutus unedo L. & Cistus monspeliensis L. \\
\hline Buxus sempervirens L. & Cistus salviifolius L. \\
\hline Cedrus libani A. Rich. & Lavandula spp. \\
\hline Ceratonia siliqua L. & Erica spp. \\
\hline Coryaria mirtifolia L. & Genista spp. \\
\hline Cupressus sempervirens L. & \\
\hline Daphne laureola L. & \\
\hline Ephedra fragilis Desf. & \\
\hline Ilex aquifolium L. & \\
\hline Juniperus excelsa M. Bieb. & \\
\hline
\end{tabular}


Table 1. Cont.

\begin{tabular}{|c|c|}
\hline Tertiary (Pre-Mediterranean *) & Quaternary (Mediterranean *) \\
\hline \multicolumn{2}{|l|}{ Juniperus macrocarpa Sm. } \\
\hline \multicolumn{2}{|l|}{ Juniperus phoenicea L. } \\
\hline \multicolumn{2}{|l|}{ Juniperus oxycedrus L. } \\
\hline \multicolumn{2}{|l|}{ Juniperus thurifera L. } \\
\hline \multicolumn{2}{|l|}{ Laurus nobilis L. } \\
\hline \multicolumn{2}{|l|}{ Myrtus communis L. } \\
\hline \multicolumn{2}{|l|}{ Nerium oleander L. } \\
\hline \multicolumn{2}{|l|}{ Pinus brutia Ten. } \\
\hline \multicolumn{2}{|l|}{ Pinus halepensis Mill. } \\
\hline \multicolumn{2}{|l|}{ Pinus nigra J. F. Arnold } \\
\hline \multicolumn{2}{|l|}{ Pinus pinaster Ait. } \\
\hline \multicolumn{2}{|l|}{ Pinus peuce Griseb } \\
\hline \multicolumn{2}{|l|}{ Pinus sylvestris L. } \\
\hline \multicolumn{2}{|l|}{ Pistacia lentiscus L. } \\
\hline \multicolumn{2}{|l|}{ Pistacia terebinthus L. } \\
\hline \multicolumn{2}{|l|}{ Pyracantha coccinea M. Roem. } \\
\hline \multicolumn{2}{|l|}{ Phillyrea angustifolia L. } \\
\hline \multicolumn{2}{|l|}{ Phillyrea latifolia L. } \\
\hline \multicolumn{2}{|l|}{ Punica granatum L. } \\
\hline \multicolumn{2}{|l|}{ Olea europaea L. } \\
\hline \multicolumn{2}{|l|}{ Quercus coccifera $\mathrm{L}$. } \\
\hline \multicolumn{2}{|l|}{ Quercus ilex $\mathrm{L}$. } \\
\hline \multicolumn{2}{|l|}{ Quercus faginea Lam. } \\
\hline \multicolumn{2}{|l|}{ Quercus suber L. } \\
\hline \multicolumn{2}{|l|}{ Rhamnus alaternus L. } \\
\hline \multicolumn{2}{|l|}{ Ruscus aculeatus L. } \\
\hline \multicolumn{2}{|l|}{ Smilax aspera $\mathrm{L}$. } \\
\hline Tetraclinis articulata (Vahl) Mast. & \\
\hline Viburnum tinus L. & \\
\hline
\end{tabular}

* Pre-Mediterranean and * Mediterranean according to Palamarev 1987; Penuelas et al., 2000; Valiente-Banuet et al., 2006.

Today, Mediterranean sclerophyll species are widely distributed outside the Mediterranean basin, according to their evolutionary history. Therefore, their occurrence is not primarily related to the typical Mediterranean climate with winter-wet and summer-dry conditions. Species belonging to the Oleaceae family, such as Olea europaea L. and P. latifolia, spread from North Africa to Middle East in non-Mediterranean climates; the genus Pistacia (family of Anacardiaceae) evolved in Central Asia under semi-arid climate [43]; while the distribution A. unedo (Ericaceae) is connected to oceanic climatic conditions and it can be found also in the British Islands [43]. Evergreen sclerophyllous oaks of the section Ilex (sensu [44], family of Fagaceae) originated from East Asia in a subtropical wet climate and migrated to western Eurasia (Europe), through the Himalayan corridor [45,46] during the Pliocene era. In the Mediterranean basin, evergreen oaks followed ecological adaptation to the prevalent climatic conditions, i.e., level of dryness [47]. Quercus ilex subsp. ballota and Quercus coccifera L. subsp. calliprinos 
are the most drought-adapted taxa of trees, respectively, in western and eastern Mediterranean basin. Overall, $Q$. ilex can be found in quite different climatic conditions [48] and local evolution patterns have been described as adaptations to varying ecological conditions within the distribution range of this species $[49,50]$.

In a field study [51], after a severe summer drought event in Spain, the responses of species evolved under pre-Mediterranean (mostly trees) and Mediterranean (mostly shrubs) climate conditions, where the first were more damaged by drought stress than the latter. According to [52], the vulnerability or resistance to drought is better explicated by ecological and climatic conditions where a species evolved, than its phylogenetic history.

\section{Winners and Losers of Mediterranean Species under Climate Change}

The relative behaviour (i.e., physiological performances, growth, reproduction) and resistance of different Mediterranean species under increasing drought and temperature has been compared in researches by means of long-term field experiments [53]. Many papers explored the physiological drivers of the greater resistance of P. latifolia and P. lentiscus in comparison with $Q$. ilex and A. unedo, as reported in field observations [51,54] (Figure 1), and the ecological consequences of such differences in terms of species competitiveness, community composition and vegetational dynamics.

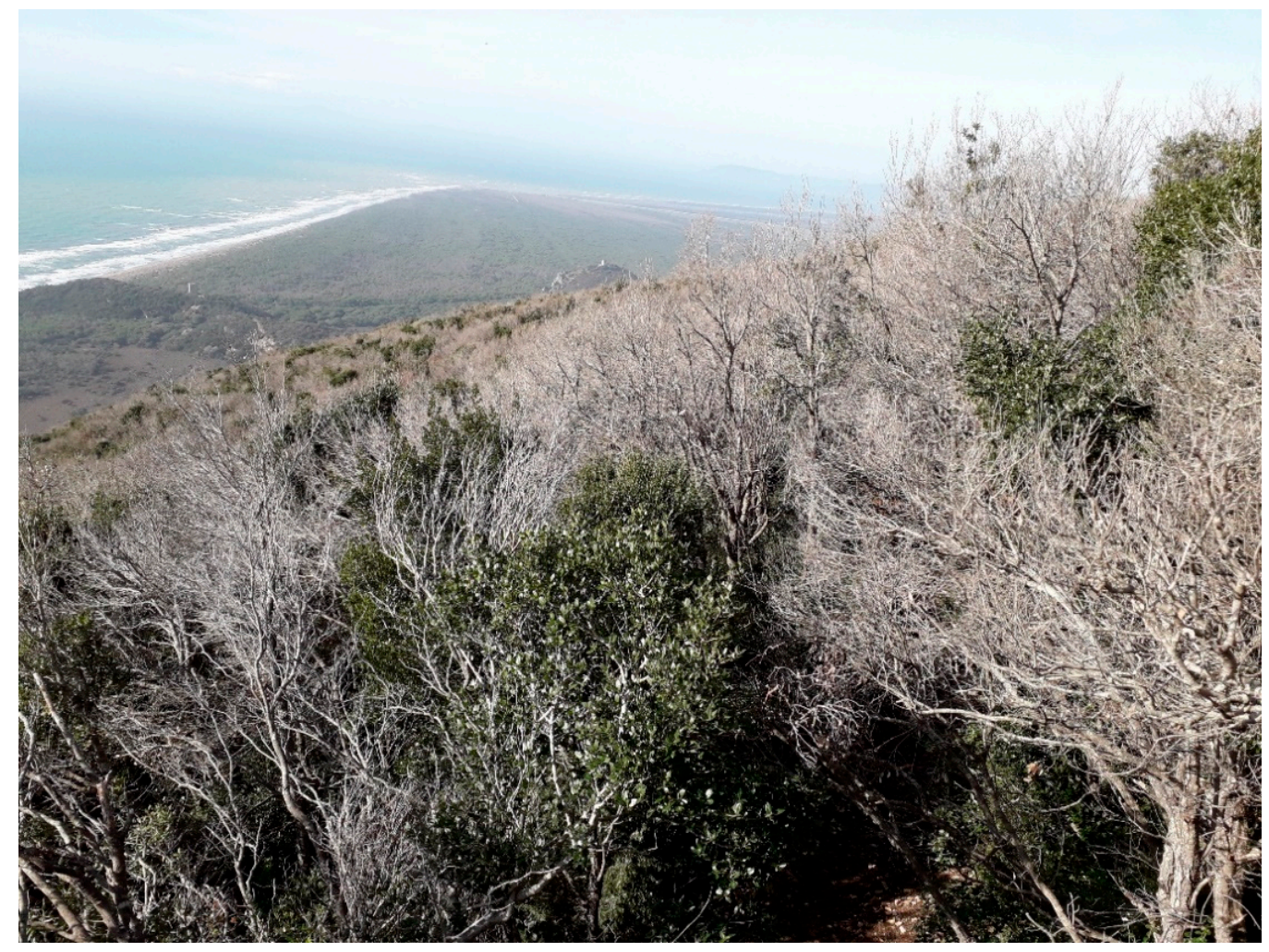

Figure 1. Quercus ilex L. (holm oak) forest stands in the Regional Park of Maremma (Tuscany, Central Italy). Trees of holm oak are completed defoliated, while Phillyrea latifolia L. trees show green canopy (photo by M. Pollastrini, 20 January 2020).

From a physiological point of view, P. latifolia and P. lentiscus showed higher photosynthetic rates and lower stomatal conductance than $Q$. ilex in water stress conditions, thus exhibiting higher instantaneous plant water use efficiencies [55]. Phillyrea latifolia survived under severe short-term drought events, whereas Q. ilex did not [55-57]. These findings were confirmed by [58] by comparing the behavior of $P$. latifolia and $Q$. ilex in field and experimental conditions. These authors found that P. latifolia can take advantage on $Q$. ilex by maintaining higher sap flow rates during dry periods. Phillyrea latifolia, 
moreover, is better performing than $Q$. ilex in drier soils: whereas $Q$. ilex assimilation rates increased with soil humidity; in P. latifolia, assimilation rates did not increase above $17 \%$ of soil humidity, showing no water availability response above such threshold [59]. Under severe drought stress, the optimal temperature for photosynthesis is $20-30 \%$ lower than in wetter conditions. This condition can overpass the high acclimatory capacity of Mediterranean trees to high air temperatures, which could provoke growth reduction rise in leaf shedding and, for some species such as A. unedo, increase mortality risk [60].

Lower water potentials in P. latifolia were not clearly associated with higher risk of hydraulic failure. Differently, hydraulic failure remains the most likely cause of death in $Q$. ilex under extreme drought [61]. The vulnerability to xylem embolism has been assessed by $[62,63]$ in a number of Mediterranean species and a pattern was proposed from the most to the lesser vulnerable: Quercus ilex $=$ Acer monspessulanum $\mathrm{L} .=$ Arbutus unedo $=$ Sorbus torminalis $\mathrm{L} .=$ Cistus laurifolius $\mathrm{L} .>$ Cistus albidus $\mathrm{L}$. $=$ Ilex aquifolium $\mathrm{L} .>$ Phillyrea latifolia $>$ Juniperus oxycedrus $\mathrm{L}$.

Concerning the reproductive processes [64], reporting the results of an experimental drought suggest that in a drier environment drought-resistant species such as P. latifolia could present greater ability to produce reproductive structures than less-resistant species, such as $Q$. ilex or $A$. unedo. In $Q$. ilex and $A$. unedo, flower and specifically fruit production were strongly correlated with annual rainfall, but not in P. latifolia. Experimental drought, tested by [65], reduced flower and fruit production in Q. ilex by $30 \%$ and $45 \%$, respectively, whereas they were not significant in A. unedo and P. latifolia.

Overall results induced [66-68] speculation that in the drier conditions predicted in Mediterranean area, a relevant reduction of tree growth rates can be expected, combined with an increase of diffusion of drought-tolerant species, such as P. latifolia, in detriment of more mesic species, such as Q. ilex. In a 14-year-long field experiment, $[69,70]$ observed that $A$. unedo was the only species showing a significant reduction in basal area increment (BAI) under drought. By contrast, $Q$. ilex reduced stem growth only during the first 4 years of treatment and P. latifolia remained unaffected over the whole study period. Moreover, [69] found a clear association between the concentrations of NSC and defoliation in Q. ilex, with lower total concentrations of NSC and a lower proportion of starch in defoliated individuals. Finally, P. latifolia was more able to retain nutrient stocks ( $\mathrm{C}$ and $\mathrm{N}$ ) under drought conditions [71].

Different responses among species could produce different patterns in tree mortality, changes in seedling recruitment, resprouting ability (by suppressed and latent buds) and, in the longer term, in species distribution. It is highly likely that mesic species such as $Q$. ilex lose competitive advantage in the drier environment forecasted for next decades than the more xeric P. latifolia and P. lentiscus [64].

\section{Impacts and Recovery in Mediterranean Vegetation}

The maintenance of the community structure and plant species composition of the Mediterranean ecosystems is connected to their ability to recover after the impacts of repeated environmental stress and disturbances (i.e., drought, fire). Evergreen sclerophyllous species have a strong capacity of vegetative regeneration (resprouting) and can restore the stand before the disturbance in relatively short time. Evidences suggest that plant communities dominated by resprouter species (RS) recover from disturbance more quickly than those composed by non-resprouters (NRS). The ability of resprouter species to resist drought and avoid mortality, combined with their ability to restore, totally or partially, defoliated crowns, prompts that the impact of increased drought stress in communities dominated by these species may be smaller [72] than in those of non-resprouters. It is necessary, however, in RS to preserve the vitality of the cambium tissue, to allow the production of adventitious buds. Extraordinarily strong drought events may lead to the shrinkage of cambium [73], thus reducing the recovery ability of woody species. In addition, the ability to produce adventitious buds declines with the age of trees and stem size $[74,75]$.

Although resprouting capacity is advantageous in stressful conditions, there are some metabolic costs to sustain, as lower seed production, higher allocation of biomass to roots than to stem and crown, and longer time to reach sexual maturity [72]. Resprouting species, moreover, need greater allocation 
resources to roots than shoots and greater non-structural carbohydrate (NSC) stores to support the growth of shoots [72]. Drought, as well many other stress factors, implies the consumption of NSC reserves [76]. In a meta-analysis study, [77] compare responses of woody species to drought intensity and duration, in terms of soluble sugars, starch, and total non-structural carbohydrates (TNSC), in leaf, stem, and root. Starch decreased in all organs, while soluble sugars increased in leaf with prolonged experiment time. The changes in soluble sugars in all organs were stronger under severe drought than under slight-to-moderate drought. Under slight-to-moderate drought, trees increased carbon storage, by means of physiological regulation processes, in order to reduce the risks of carbon starvation. In contrast, long-term severe drought could lead to NSC depletion in the whole plant, so reducing the ability to recover after stress. Barbeta and Peñuelas [78] found this process in Q. ilex, which can vigorously resprout after drought episodes, but its resilience (i.e., the ability to cope with further stressful events) may be reduced. In the future, the higher frequency of recurrence of extreme droughts will be a challenge for plant communities, and thus, the capacity of these forests to recover.

The time occurring for a (more or less) complete recovery of NSC reserves is therefore crucial for the resilience of Mediterranean vegetation subjected to dry spell events. Research focused on evaluating the development of crown conditions and NSC stored in lignotubers 7 years after a drought event [79] showed that crown dieback was associated with a depletion of the carbon reserves in lignotubers. López et al. [80] found that, 10 years after a drought event, starch stocks in the lignotubers have recovered to half the former amount. In a study [80], it was pointed out that more frequent droughts may provoke a progressive depletion of carbon reserves and a loss of resilience in Mediterranean resprouter species.

Concerning the recovery by sexual reproduction processes (i.e., by seeds), increased drought reduces acorn production in Q. ilex [81]. The effects of drought on seed production and germinative ability may be different according to the sensitivity of each species to water stress [64]. Drought, moreover, can modify the local conditions of the soil by affecting the mycorrhizal status and thus the establishment of seedlings [82].

The combination of sexual and vegetative regeneration, together with individual and species competition processes, drives the dynamic of vegetation after a climatic impact. An analysis of the situation 6 years after a severe drought event in the Iberian peninsula [14] evidenced that the loss of canopy cover, mainly composed by $Q$. ilex, was not still recovered, and the more drought-tolerant species $P$. latifolia tended to increase its relative abundance in the upper vegetation canopy. In addition, early successional shrubs, such as Cistus sp.pl., increased their abundance in the understorey.

\section{Which Future for Mediterranean Vegetation?}

The analysis of literature, together with our surveys and field observations, evidenced that severe drought events selectively impact the Mediterranean woody species. The Mediterranean basin is considered a "biodiversity hotspot" [83], characterized by forests and shrublands with many species with different phylogeny and evolutionary history. The different sensitivity of the current Mediterranean species to drought may depend on the region of species origin and subsequently from the adaptation to the climatic evolution [52]. In the Mediterranean region, the genetic richness of the plant communities is an essential resource that makes possible the evolution of ecosystems in different ways, in accordance with the change of the main environmental drivers. Increasing dryness may favor the best adapted species, which originated in drier regions, or under typical Mediterranean climate, namely in the Quaternary period [42]. For these reasons, we can hypothesize that instead of latitudinal (South to North) or altitudinal (lowland to upland) migrations [84], Mediterranean forest ecosystems may respond to climate change by modulating their composition and structure with the genetic resources already present in loco. Possible interventions of "assisted migration" [85], to assure land cover and soil protection, should take into consideration taxa and provenances that originated from the driest regions of Mediterranean and summer deciduous species. 
Experimental evidences [86] suggest that Q. ilex seedlings that originated from mother trees of different provenances show distinct behaviors and sensitivity to drought stress in relation to the ecology of the origin population. These findings indicate a local evolution with differentiation of distinct ecotypes, or the triggering of mechanisms of epigenetic responses and trans-generational memory [87-89]. Epigenetic regulation is an important mechanism for plant adaptation to changing environment without DNA alteration. Plants cannot adapt their behavior or migrate instantly, so phenotypic plasticity and epigenetic responses are crucial for the survival of plants [90].

\section{Conclusions}

The impact of climate change, including extreme heat and drought waves, on Mediterranean evergreen forest vegetation and the subsequent recovery or changes in composition, structure and ecosystem functioning, is a current environmental issue that can potentially interest wider areas. It is essential, therefore, to address researches on Mediterranean ecosystems' vulnerability to environmental impacts and to catch the attention of forest managers and stakeholders on what is happening and the future risks. Below we list the most relevant points to be addressed in future researches.

First, we need to better understand the physiological processes of the vegetative regeneration, the role of NSC and the resilience of trees severely damaged by drought. The relevant question is how many years after the stress event and which climatic and environmental conditions are needed to restore the NSC reserves and the full functionality of plants. According to [91], from the beginning of the 21 st century, severe drought events have been recurrent every $4-5$ years in Central Italy.

Secondly, the sexual regeneration poses further problems, concerning the quantity and quality of seed produced by damaged plants. A specific question is connected to a possible memory of the stress [92] as a factor that improves the epigenetic adaptation to the new environment.

Then, it is necessary to investigate the different sensitivities to drought of a wider range of Mediterranean woody species, to define the limits of the stress that can be tolerated even by the most resistant species, and the distinct mechanisms to withstand with drought [93,94].

Finally, extreme drought events bring the vegetational dynamics back to the initial stages. The natural processes of forest reconstruction must be observed in long term permanent areas, by developing and integrating the forest monitoring networks already existing [6,95]. Changes in vegetational assemblages and structure may lead to changes in ecological and landscape characteristics and values, with corresponding ecosystem services, including bio-economic aspects and touristic fruition. That requires a redefinition of management criteria and a pro-active silviculture to make the ecosystems more resilient.

Author Contributions: F.B. wrote the first draft; M.P. wrote, reviewed and editing the manuscript. All authors have read and agreed to the published version of the manuscript.

Funding: This research received no external funding.

Conflicts of Interest: The Authors declare no conflict of interest.

\section{References}

1. Allen, C.D.; Macalady, A.K.; Chenchouni, H.; Bachelet, D.; McDowell, N.; Vennetier, M.; Kitzberger, T.; Rigling, A.; Breshears, D.D.; Hogg, E.H.; et al. A global overview of drought and heat-induced tree mortality reveals emerging climate change risks for forests. For. Ecol. Manag. 2010, 259, 660-684. [CrossRef]

2. Allen, C.D.; Breshears, D.D.; McDowell, N.G. On underestimation of global vulnerability to tree mortality and forest die-off from hotter drought in the Anthropocene. Ecosphere 2015, 6, 1-55. [CrossRef]

3. Anderegg, W.R.L.; Kane, J.M.; Anderegg, L.D.L. Consequences of widespread tree mortality triggered by drought and temperature stress. Nat. Clim. Chang. 2013, 3, 30-36. [CrossRef]

4. Anderegg, W.R.; Hicke, J.A.; Fisher, R.A.; Allen, C.D.; Aukema, J.; Bentz, B.; Hood, S.; Lichstein, J.W.; Macalady, A.K.; McDowell, N.; et al. Tree mortality from drought, insects, and their interactions in a changing climate. New Phytol. 2015, 208, 674-683. [CrossRef] 
5. Bussotti, F.; Pollastrini, M. Observing climate change impacts on European forests: What works and what does not in ongoing long-term monitoring networks. Front. Plant Sci. 2017, 8, 629. [CrossRef]

6. Choat, B.; Brodribb, T.J.; Brodersen, C.R.; Duursma, R.A.; López, R.; Medlyn, B.E. Triggers of tree mortality under drought. Nature 2018, 558, 531-539. [CrossRef]

7. Hartmann, H.; Schuldt, B.; Sanders, T.G.M.; Macinnis-Ng, C.; Boehmer, H.J.; Allen, C.D.; Bolte, A.; Crowther, T.W.; Hansen, M.C.; Medlyn, B.E.; et al. Monitoring global tree mortality patterns and trends. Report from the VW symposium 'Crossing scales and disciplines to identify global trends of tree mortality as indicators of forest health'. New Phytol. 2018, 217, 984-987. [CrossRef]

8. Breda, N.; Huc, R.; Granier, A.; Dreyer, E. Temperate forest trees and stands under severe drought: A review of ecophysiological responses, adaptation processes and long-term consequences. Annal. For. Sci. 2006, 63, 625-644. [CrossRef]

9. Schuldt, B.; Buras, A.; Arend, M.; Vitasse, Y.; Beierkuhnlein, C.; Damm, A.; Gharun, M.; Grams, T.E.E.; Hauck, M.; Hajek, P.; et al. A first assessment of the impact of the extreme 2018 summer drought on Central European forests. Basic Appl. Ecol. 2020, 45, 86-103. [CrossRef]

10. Bussotti, F.; Ferrini, F.; Pollastrini, M.; Fini, A. The challenge of Mediterranean sclerophyllous vegetation under climate change: From acclimation to adaptation. Environ. Exp. Bot. 2014, 103, 80-98. [CrossRef]

11. Peñuelas, J.; Filella, I.; Llusià, J.; Piñol, J.; Siscart, D. Effects of a severe drought on water and nitrogen use by Quercus ilex and Phillyrea latifolia. Biol. Plant. 2000, 43, 47-53.

12. Lloret, F.; Siscart, D.; Dalmases, C. Canopy recovery after drought dieback in holm-oak Mediterranean forests of Catalonia (NE Spain). Glob. Chang. Biol. 2004, 10, 2092-2099. [CrossRef]

13. Saura-Mas, S.; Bonas, A.; Lloret, F. Plant community response to drought-induced canopy defoliation in a Mediterranean Quercus ilex forest. Eur. J. For. 2015, 134, 261-272. [CrossRef]

14. Puletti, N.; Mattioli, W.; Bussotti, F.; Pollastrini, M. Monitoring the effects of extreme drought events on forest health by Sentinel-2 imagery. J. Appl. Remote Sens. 2019, 13, 020501. [CrossRef]

15. Pollastrini, M.; Puletti, N.; Selvi, F.; Iacopetti, G.; Bussotti, F. Widespread crown defoliation after a drought and heat wave in the forests of Tuscany (central Italy) and their recovery-a case study from summer 2017. Front. For. Glob. Chang. 2019, 2, 74. [CrossRef]

16. Caudullo, G.; Barredo, J. A georeferenced dataset of drought and heat induced tree mortality in Europe. One Ecosyst. 2019, 4, e37753. [CrossRef]

17. Barbeta, A.; Ogaya, R.; Peñuelas, J. Dampening effects of long-term experimental drought on growth and mortality rates of a Holm oak forest. Glob. Chang. Biol. 2013, 19, 3133-3144. [CrossRef]

18. Pausas, J.G. Mediterranean vegetation dynamics: Modelling problems and functional Types. Plant Ecol. 1999, 140, 27-39. [CrossRef]

19. Di Castri, F.; Goodall, D.W.; Specht, R.L. Mediterranean-Type Shrublands, Ecosystems of the World, 11st ed.; Elsevier: Amsterdam, The Netherlands; Oxford, UK; New York, NY, USA, 1981; ISBN 0-444-411858-X.

20. Salleo, S.; Nardini, A.; Lo Gullo, M.A. Is sclerophylly of Mediterranean evergreens an adaptation to drought? New Phytol. 1997, 135, 603-612. [CrossRef]

21. Alonso-Forn, D.; Sancho-Knapik, D.; Ferrio, J.P.; Peguero-Pina, J.J.; Bueno, A.; Onoda, Y.; Cavender-Bares, J.; Niinemets, Ü.; Jansen, S.; Riederer, M.; et al. Revisiting the functional basis of sclerophylly within the leaf economics spectrum of oaks: Different roads to Rome. Curr. For. Rep. 2020, 6, 260-281. [CrossRef]

22. Blumler, M.A. Winter-Deciduous versus Evergreen Habit in Mediterranean Regions: A Model. In Proceedings of the Symposium on Oak Woodlands and Hardwood Rangeland Management, Davis, CA, USA, 31 October-2 November 1991; pp. 194-197.

23. Blumler, M.A. Three conflated definitions of Mediterranean climates. Middle Stat. Geogr. 2005, 38, 52-60.

24. Aerts, R. The advantages of being evergreen. Tree 1995, 10, 4012-4407. [CrossRef]

25. Diamantoglou, S.; Rhizopoulou, S.; Kull, U. Energy content, storage substances, and construction and maintenance costs of Mediterranean deciduous leaves. Oecologia 1989, 81, 528-533. [CrossRef] [PubMed]

26. Tang, L.Y.; Han, W.X.; Chen, Y.H.; Fang, J.Y. Resorption proficiency and efficiency of leaf nutrients in woody plants in eastern China. J. Plant Ecol. 2013, 6, 408-417. [CrossRef]

27. Mooney, H.A.; Dunn, E.L. Convergent evolution in mediterranean-climate evergreen sclerophyll shrubs. Evolution 1970, 24, 292-303. [CrossRef]

28. Mooney, H.A.; Dunn, E.L. Photosynthetic systems of mediterranean-climate shrubs and trees of California and Chile. Am. Nat. 1970, 104, 447-453. [CrossRef] 
29. Flexas, J.; Diaz-Espejo, A.; Gago, J.; Gallé, A.; Galmés, J.; Gulías, J.; Medrano, H. Photosynthetic limitations in Mediterranean plants: A review. Environ. Exp. Bot. 2014, 103, 12-23. [CrossRef]

30. Damesin, C.; Rambal, S. Field study of leaf photosynthetic performance by a Mediterranean deciduous oak tree (Quercus pubescens) during a severe summer drought. New Phytol. 1995, 131, 159-167.

31. Baldocchi, D.D.; Ma, S.; Rambal, S.; Misson, L.; Ourcival, J.M.; Limousin, J.M.; Pereira, J.; Papale, D. On the differential advantages of evergreenness and deciduousness in mediterranean oak woodlands: A flux perspective. Ecol. Appl. 2010, 20, 1583-1597. [CrossRef]

32. Tognetti, R.; Longobucco, A.; Raschi, A. Vulnerability of xylem to embolism in relation to plant hydraulic resistance in Quercus pubescens and Quercus ilex co-occurring in a Mediterranean coppice stand in central Italy. New Phytol. 1998, 139, 437-447. [CrossRef]

33. Salleo, S.; Trifilò, P.; Esposito, S.; Nardini, A.; Lo Gullo, M.A. Starch-to-sugar conversion in wood parenchyma of field growing Laurus nobilis plants: A component of the signal pathway for embolism repair? Funct. Plant Biol. 2009, 36, 815-825. [CrossRef] [PubMed]

34. Meinzer, F.C.; Mc Culloh, K.A. Xylem recovery from drought-induced embolism: Where is the hydraulic point of no return? Tree Physiol. 2013, 33, 331-334. [CrossRef] [PubMed]

35. Christman, M.A.; Sperry, J.S.; Smith, D.D. Rare pits, large vessels and extreme vulnerability to cavitation in a ring-porous tree species. New Phytol. 2012, 193, 713-720. [CrossRef] [PubMed]

36. Trifilò, P.; Kiorapostolou, N.; Petruzzelli, F.; Vitti, S.; Petit, G.; Lo Gullo, M.A.; Nardini, A.; Casolo, V. Hydraulic recovery from xylem embolism in excised branches of twelve woody species: Relationships with parenchyma cells and non-structural carbohydrates. Plant Physiol. Bioch. 2019, 139, 513-520. [CrossRef]

37. Grammatikopoulos, G.; Kyparissis, A.; Manetas, Y. Seasonal and diurnal gas exchange characteristics and water relations of the drought semi-deciduous shrub Phlomis fruticosa L. under Mediterranean field conditions. Flora 1995, 190, 71-78. [CrossRef]

38. Givnish, T.J. Adaptive Significance of Evergreen vs. Deciduous Leaves: Solving the Triple Paradox. Silva Fenn. 2002, 36, 703-743. [CrossRef]

39. Kondraskov, P.; Schütz, N.; Schüßler, C.; de Sequeira, M.M.; Guerra, A.S.; Caujapé-Castells, J.; Jaén-Molina, R.; Marrero-Rodríguez, Á.; Koch, M.A.; Linder, P.; et al. Biogeography of Mediterranean Hotspot Biodiversity: Re-Evaluating the 'Tertiary Relict' Hypothesis of Macaronesian Laurel Forests. PLoS ONE 2015, 10, e0132091. [CrossRef]

40. Herrera, C.M. Historical effects and sorting processes as explanation for contemporary ecological patterns: Character syndromes in mediterranean woody plants. Am. Nat. 1992, 140, 421-446. [CrossRef]

41. Cheng, Q.; Yu-Sheng, C.L.; Hui, T.; Torsten, U. Miocene shift of European atmospheric circulation from trade wind to westerlies. Sci. Rep. 2014, 4, 5660.

42. Neil, R.; Meadows, M.E.; Dodson, J.R. The history of mediterranean-type environments: Climate, culture and landscape. Holocene 2001, 6, 631-634.

43. Verdú, M.; Dávila, P.; García-Fayos, P.; Flores-Hernández, N.; Valiente-Banuet, A. 'Convergent' traits of mediterranean woody plants belong to pre-mediterranean lineages. Biol. J. Linn. Soc. 2003, 78, 415-427. [CrossRef]

44. Valiente-Banuet, A.; Vital Rumebe, A.; Verdù, M.; Callaway, R.M. Modern Quaternary plant lineages promote diversity through facilitation of ancient Tertiary lineages. PNAS 2006, 103, 16812-16817. [CrossRef] [PubMed]

45. Zohary, M. Geobotanical Foundations of the Middle East; Gustav Fischer: Stuttgart, Germany, 1973.

46. Sealy, J.R.; Webb, D.A. Biological Flora of British Islands. Arbutus unedo L. J. Ecol. 1950, 38, 223-236. [CrossRef]

47. Denk, T.; Grimm, G.W. The oaks of western Eurasia: Traditional classifications and evidence from two nuclear markers. Taxon 2010, 59, 351-366. [CrossRef]

48. Denk, T.; Grimm, G.W.; Manos, P.S.; Deng, M.; Hipp, A.L. An Updated Infrageneric Classification of the Oaks: Review of Previous Taxonomic Schemes and Synthesis of Evolutionary Patterns. In Oaks Physiological Ecology. Exploring the Functional Diversity of Genus Quercus L., Tree Physiology, 7; Gil-Pelegrin, E., Peguero-Pina, J.J., Sancho-Knapik, D., Eds.; Springer International Publishing: Berlin/Heidelberg, Germany, 2017; pp. 13-38.

49. Denk, T.; Velitzelos, D.; Güner, T.H.; Bouchal, J.M.; Grimsson, F.; Grimm, G.W. Taxonomy and palaeoecology of two widespread western Eurasian Neogene sclerophyllous oak species: Quercus drymeja Unger and Q. mediterranea Unger. Rev. Palaeobot. Palynol. 2017, 241, 98-128. [CrossRef] 
50. Peguero-Pina, J.J.; Sancho-Knapik, D.; Barrón, E.; Camarero, J.J.; Vilagrosa, A.; Gil-Pelegrín, E. Morphological and physiological divergences within Quercus ilex support the existence of different ecotypes depending on climatic dryness. Ann. Bot. 2014, 114, 301-313. [CrossRef]

51. Barbero, M.; Loisel, R.; Quézel, P. Biogeography, ecology and history of Mediterranean Quercus ilex ecosystems. In Quercus ilex L. Ecosystems: Function, Dynamics and Management; Romane, F., Terradas, J., Eds.; Advances in Vegetation Science; Springer: Dordrecht, The Netherlands, 1992; Volume 13.

52. Gratani, L.; Meneghini, M.; Pesoli, P.; Crescente, M.F. Structural and functional plasticity of Quercus ilex seedlings of different provenances in Italy. Trees 2003, 17, 515-521. [CrossRef]

53. García-Nogales, A.; Linares, J.C.; Laureano, R.G.; Seco, J.I.; Merino, J. Range-wide variation in life-history phenotypes: Spatiotemporal plasticity across the latitudinal gradient of the evergreen oak Quercus ilex. J. Biogeogr. 2016, 43, 2366-2379. [CrossRef]

54. Peñuelas, J.; Lloret, F.; Montoya, R. Severe Drought Effects on Mediterranean Woody Flora in Spain. For. Sci. 2001, 47, 214-218.

55. Münzbergová, Z.; Kosová, V.; Schnáblová, R.; Rokaya, M.; Synková, H.; Haisel, D.; Wilhelmová, N.; Dostálek, T. Plant Origin, but Not Phylogeny, Drive Species Ecophysiological Response to Projected Climate. Front. Plant Sci. 2020, 11, 400. [CrossRef]

56. Peñuelas, J.; Sardans, J.; Filella, I.; Estiarte, M.; Llusià, J.; Ogaya, R.; Carnicer, J.; Bartons, M.; Rivas-Ubach, A.; Grau, D. Assessment of the impacts of climate change on Mediterranean terrestrial ecosystems based on data from field experiments and long-term monitored field gradients in Catalonia. Environ. Exp. Bot. 2018, 152, 49-59.

57. Peñuelas, J.; Filella, I.; Lloret, F.; Siscart, D.; Piñol, J. Comparative field study of spring and summer leaf gas exchange and photobiology of the Mediterranean trees Quercus ilex and Phillyrea latifolia. J. Exp. Bot. 1998, 49, 229-238. [CrossRef]

58. Filella, I.; Llusiá, J.; Piñol, J.; Peñuelas, J. Leaf gas exchange and fluorescence of Phillyrea latifolia, Pistacia lentiscus and Quercus ilex saplings in severe drought and high temperature conditions. Environ. Exp. Bot. 1998, 39, 213-220. [CrossRef]

59. Ogaya, R.; Llusià, J.; Barbeta, A.; Asensio, D.; Liu, D.; Alessio, G.A.; Penuelas, J. Foliar CO2 in a holm oak forest subjected to 15 years of climate change simulation. Plant Sci. 2014, 226, 101-107. [CrossRef]

60. Barbeta, A.; Ogaya, R.; Peñuelas, J. Comparative study of diurnal and nocturnal sap flow of Quercus ilex and Phillyrea latifolia in a Mediterranean holm oak forest in Prades (Catalonia, NE Spain). Trees 2012, 26, 1651-1659. [CrossRef]

61. Ogaya, R.; Peñuelas, J. Comparative field study of Quercus ilex and Phillyrea latifolia: Photosynthetic response to experimental drought conditions. Environ. Exp. Bot. 2003, 50, 137-148. [CrossRef]

62. Sperlich, D.; Chang, C.T.; Peñuelas, J.; Sabaté, S. Responses of photosynthesis and component processes to drought and temperature stress: Are Mediterranean trees fit for climate change? Tree Physiol. 2019, 39, 1783-1805. [CrossRef] [PubMed]

63. Garcia-Forner, N.; Biel, C.; Savé, R.; Martínez-Vilalta, J. Isohydric species are not necessarily more carbon limited than anisohydric species during drought. Tree Physiol. 2019, 37, 441-455. [CrossRef] [PubMed]

64. Martínez-Vilalta, J.; Prat, E.; Oliveras, I.; Piñol, J. Xylem hydraulic properties of roots and stems of nine Mediterranean woody species. Oecologia 2002, 133, 19-29. [CrossRef]

65. Martínez-Vilalta, J.; Mangirón, M.; Ogaya, R.; Sauret, M.; Serrano, L.; Peñuelas, J.; Piñol, J. Sap flow of three co-occurring Mediterranean woody species under varying atmospheric and soil water conditions. Tree Physiol. 2003, 23, 747-758. [CrossRef]

66. Ogaya, R.; Peñuelas, J. Phenological patterns of Quercus ilex, Phillyrea latifolia, and Arbutus unedo growing under a field experimental drought. Ecoscience 2004, 11, 263-270. [CrossRef]

67. Ogaya, R.; Penuelas, J. Species-specific drought effects on flower and fruit production in a Mediterranean holm oak forest. Forestry 2007, 80, 351-357. [CrossRef]

68. Ogaya, R.; Peñuelas, J.; Martínez-Vilalta, J.; Mangirón, M. Effect of drought on diameter increment of Quercus ilex, Phillyrea latifolia, and Arbutus unedo in a holm oak forest of NE Spain. For. Ecol. Manag. 2003, 180, 176-184. [CrossRef]

69. Ogaya, R.; Penuelas, J. Tree growth, mortality, and above-ground biomass accumulation in a holm oak forest under a five-year experimental field drought. Plant Ecol. 2007, 189, 291-299. [CrossRef] 
70. Ogaya, R.; Barbeta, A.; Başnou, C.; Penuelas, J. Satellite data as indicators of tree biomass growth and forest dieback in a Mediterranean holm oak forest. Ann. For. Sci. 2015, 72, 135-144. [CrossRef]

71. Rosas, T.; Galiano, L.; Ogaya, R.; Peñuelas, J.; Martinez-Vilalta, J. Dynamics of non-structural carbohydrate in three Mediterranean woody species Following long-term experimental drought. Front. Plant Sci. 2013, 4, 400. [CrossRef]

72. Liu, D.; Ogaya, R.; Barbeta, A.; Yang, X.; Penuelas, J. Contrasting impacts of continuous moderate drought and episodic severe droughts on the aboveground biomass increment and litterfall of three coexisting Mediterranean woody species. Glob. Chang. Biol. 2015, 21, 4196-4209. [CrossRef]

73. Sardans, J.; Urbina, I.; Grau, O.; Asensio, D.; Ogaya, R.; Peñuelas, J. Long-term drought decreases ecosystem $\mathrm{C}$ and nutrient storage in a Mediterranean holm oak forest. Environ. Exp. Bot. 2020, 177, 104135. [CrossRef]

74. Zeppel, M.J.B.; Harrison, S.P.; Adams, H.D.; Kelley, D.I.; Li, G.; Tissue, D.T.; Dawson, T.E.; Fensham, R.; Medlyn, B.E.; Palmer, A.; et al. Drought and resprouting plants. New Phytol. 2015, 206, 583-589. [CrossRef]

75. Li, S.; Jansen, S. The root cambium ultrastructure during drought stress in Corylus avellane. IAWA J. 2017, 38, 67-80. [CrossRef]

76. Vesk, P.; Westoby, M. Sprouting ability across diverse disturbances and vegetation types worldwide. J. Ecol. 2004, 92, 310-320. [CrossRef]

77. Vesk, P. Plant size and resprouting ability: Trading tolerance and avoidance of damage? J. Ecol. 2006, 94, 1027-1034. [CrossRef]

78. Hartmann, H.; Trumbore, S. Understanding the roles of nonstructural carbohydrates in forest trees-from what we can measure to what we want to know. New Phytol. 2016, 211, 386-403. [CrossRef] [PubMed]

79. He, W.; Liu, H.; Qi, Y.; Liu, F.; Zhu, X. Patterns in nonstructural carbohydrate contents at the tree organ level in response to drought duration. Glob Chang. Biol. 2019, 26, 3627-3638. [CrossRef] [PubMed]

80. Barbeta, A.; Peñuelas, J. Sequence of plant responses to droughts of different timescales: Lessons from holm oak (Quercus ilex) forests. Plant. Ecol. Div. 2016, 9, 321-338. [CrossRef]

81. Galiano, L.; Martinez-Vilalta, J.; Sabaté, S.; Lloret, F. Determinants of drought induced effects on crown condition and their relationship with depletion of carbon reserve in a Mediterranean holm oak forest. Tree Physiol. 2012, 32, 478-489. [CrossRef] [PubMed]

82. López, B.C.; Gracia, C.A.; Sabaté, S.; Keenan, T. Assessing the resilience of Mediterranean holm oaks to disturbances using selective thinning. Acta Oecol. 2009, 35, 849-854. [CrossRef]

83. Sánchez-Humanes, B.; Espelta, J.M. Increased drought reduces acorn production in Quercus ilex coppices: Thinning mitigates this effect but only in the short term. Forestry 2011, 84, 73-82. [CrossRef]

84. García de Jalón, L.; Limousin, J.M.; Richard, F.; Gessler, A.; Peter, M.; Hättenschwiler, S.; Milcu, A. Microhabitat and ectomycorrhizal effects on the establishment, growth and survival of Quercus ilex L. seedlings under drought. PLoS ONE 2020, 15, e0229807. [CrossRef]

85. Fady-Welterlen, B. Is there really more biodiversity in Mediterranean forest ecosystems? Taxon 2005, 54, 905-910. [CrossRef]

86. Hanewinkel, M.; Cullmann, D.A.; Schelhaas, M.J.; Nabuurs, G.J.; Zimmermann, N.E. Climate change may cause severe loss in the economic value of European forest land. Nat. Clim. Chang. 2013, 3, $203-207$. [CrossRef]

87. Koralewski, T.E.; Wang, H.H.; Grant, W.E.; Byram, T.D. Plants on the move: Assisted migration of forest trees in the face of climate change. For. Ecol. Manag. 2015, 344, 30-37. [CrossRef]

88. Rico, L.; Ogaya, R.; Barbeta, A.; Peñuelas, J. Changes in DNA methylation fingerprint of Quercus ilex trees in response to experimental field drought simulating projected climate change. Plant Biol. 2004, 16, 419-427. [CrossRef] [PubMed]

89. Walter, J.; Jentsch, A.; Beierkuhnlein, C.; Kreyling, J. Ecological stress memory and cross stress tolerance in plants in the face of climate extremes. Environ. Exp. Bot. 2013, 94, 3-8. [CrossRef]

90. Backhaus, S.; Kreyling, J.; Grant, K.; Beierkuhnlein, C.; Walter, J.; Jentsch, A. Recurrent Mild Drought Events Increase Resistance Toward Extreme Drought Stress. Ecosystems 2014, 17, 1068-1081. [CrossRef]

91. Bose, A.; Moser, B.; Rigling, A.; Lehmann, M.M.; Milcu, A.; Peter, M.; Rellstab, C.; Wohlgemuth, T.; Gessler, A. Memory of environmental conditions across generations affects the acclimation potential of Scots pine. Plant Cell Environ. 2020, 43, 1288-1299. [CrossRef]

92. Balao, F.; Paun, O.; Alonso, C. Uncovering the contribution of epigenetics to plant phenotypic variation in Mediterranean ecosystems. Plant Biol. 2018, 20 (Suppl. S1), 38-49. [CrossRef] 
93. Magno, R.; De Filippis, T.; Di Giuseppe, E.; Pasqui, M.; Rocchi, L.; Gozzini, B. Semi-automatic operational service for drought monitoring and forecasting in the Tuscany region. Geosciences 2018, 8, 49. [CrossRef]

94. Bréda, N.; Badeau, V. Forest tree responses to extreme drought and some biotic events: Towards a selection according to hazard tolerance? Comptes Rendus Geosci. 2008, 340, 651-662. [CrossRef]

95. Bussotti, F.; Pollastrini, M. Traditional and novel indicators of climate change impacts on European forest trees. Forests 2017, 8, 137. [CrossRef]

Publisher's Note: MDPI stays neutral with regard to jurisdictional claims in published maps and institutional affiliations.

(C) 2020 by the authors. Licensee MDPI, Basel, Switzerland. This article is an open access article distributed under the terms and conditions of the Creative Commons Attribution (CC BY) license (http://creativecommons.org/licenses/by/4.0/). 